\title{
Micro-Econometric Analyses of Some Welfare Effects of Oil- Availability in the Niger Delta Region of Nigeria
}

\author{
Aderoju Oyefusi ${ }^{1}$ \\ ${ }^{1}$ Department of Economics and Statistics, University of Benin, Benin City, Nigeria \\ Correspondence: Aderoju Oyefusi, Department of Economics and Statistics, University of Benin, Benin City, \\ Nigeria. E-mail: aderojuoyefusi@yahoo.com, aderoju.oyefusi@uniben.edu.ng
}

\author{
Received: June 2, 2013 Accepted: October 12, 2013 Online Published: November 25, 2013 \\ doi:10.5539/jsd.v6n12p61 URL: http://dx.doi.org/10.5539/jsd.v6n12p61
}

\begin{abstract}
This article raises some fundamental issues in the resource-development literature, such as the effect of resource-availability and resource-related conflicts on personal and community-wide welfare, the interaction between resource-abundance and hopelessness, and the role of government presence and location of communities, using the Niger Delta region of Nigeria as a case study. Employing survey data from two sources, it shows that oil-availability has mixed effects for individuals and communities. It raises educational attainments and socio-economic access among individuals and infrastructural development in communities but also tends to generate higher episodes of violent conflicts, higher inequality, and greater feeling of despondency among individuals. It also fails to significantly affect earning levels or reduce unemployment. Government presence is beneficial as it tends to impact positively on earnings and socio-economic access among residents and reduces the likelihood of being unemployed or experiencing a longer spell of unemployment, but it is also likely to be associated with higher inequalities, higher incidences of conflict, and greater hopelessness. Individuals in more distant communities tend to have lower educational attainments and socio-economic access but they are also more likely to enjoy lower levels of inequality, greater hope, and lower incidences of unemployment. Youths tend to suffer the most from the negative effects of resource-abundance as they appear to be worse off on all measures of personal welfare employed, while geographical characteristics seem important for welfare just the same way as policy and initiatives at the local level. The paper concludes that natural resources, such as oil, can be significantly welfare-improving if its tendency to encourage violent conflict outbreaks can be addressed, but this may not be achieved by merely providing greater infrastructure or expanding educational opportunities but by matching these with significantly-expanded economic space.
\end{abstract}

Keywords: Niger Delta, oil, conflict, welfare, government presence, geography

\section{Introduction}

The oil-rich Niger Delta region of Nigeria has attracted much attention in the academic and policy circles in the last two decades, following outbreaks of violence and concerns about the poor state of socio-economic and human development in the region (Note 1). The first-ever human development report to focus on the region (UNDP 2006:45-46, 160) notes that even though some states have higher human development index (HDI) rankings than the Nigerian average, the human development situation is still far worse than what obtains in other regions (states) with significant oil endowments. While acknowledging the fact that communities have benefited immensely from oil, the report mentions a link between oil operations and human deprivation in some communities. It also finds that ecology, GDP, and to a lesser extent, the location of oil facilities, "best explains" HDI rankings (UNDP 2006:151-2). This paper examines some welfare effects of oil-availability in the region using a dataset based on responses from over 1, 300 individuals in 18 communities. It focuses on nine indicators of personal and community-wide welfare, including formal educational attainments, personal socio-economic access, earnings, unemployment, hope, infrastructural endowment in communities, episodes of violent conflict, and divergences in personal welfare measures among residents of the same community. The results indicate that oil has mixed effects, enhancing infrastructural endowment in host communities and educational attainments and socio-economic access among individuals, but leaving no influence on earnings levels or the likelihood of securing employment. It also tends to generate violent conflicts in communities, which in turn accentuate inequality, and to promote a feeling of despondency among individuals. Government presence in communities 
raises the likelihood of higher earnings but also significantly raises income inequalities and weakly increases violent conflict outbreaks. While residents in more distant communities tend to be worse off on some measures of welfare such as educational attainments, socio-economic access, and the incidence of violent conflict, they tend to experience less unemployment and greater equality in opportunities and to be more hopeful. Most indicators of welfare examined appear to fall with the age of respondents, indicating that youths are not only generally worse hit by the poor developmental state (see also UNDP, 2006) but are also likely to remain most vulnerable.

\section{A Theoretical Framework on Oil and Welfare}

Generally, resource-abundance has been associated with slow growth (Sachs \& Warner, 1995) and greater inequality and poverty (Gravin \& Hausmann, 1988; Ross, 2004). The situation is believed to be worse in the case of mineral resources, such as oil. Ross $(1999,2001)$ for example, linked higher mineral and oil dependence to lower HDI rankings, higher incidences of poverty, greater proportion of expenditure devoted to military spending and greater authoritarianism. Gary and Karl (2003) also note that oil has brought greater misery for most producers in Sub-Saharan Africa. In trying to establish a link between oil and welfare at the micro level, the first step is to identify the relevant indicators of welfare. From the individual's viewpoint, sustainable livelihood requires socio-economic access, including personal access to education and gainful employment. Higher education increases human capital and the ability to command higher wages, while a guaranteed flow of income through employment provides socio-economic security. In the African context where the extended family factor and social networking could be very strong, sustainable livelihood may also require that adult relations have access to employment, and that young dependants have access to education as a means of securing their own future. In this study, I use five measures of personal welfare among individuals resident in mineral-abundant regions: personal earnings, personal formal educational attainments, personal socio-economic access, unemployment, and hope. Hope, which is an expression of faith in the future, or a positive view of the future, is often viewed as an important factor in human capital asset (United Nations Development Programme (UNDP), 2006:385). I assume that personal welfare increases in access, formal educational attainment, earnings, and hope, but falls in unemployment. Notationally,

$$
\text { Personal Welfare }=f \text { (Earnings, Education, Access, Unemployment, Hope) }
$$

There are various possible indicators of collective (community-wide) welfare in a mineral-abundant region. In this study, I focus on three. The first is the endowment of socio-economic infrastructure in communities; the second is peace/conflict occurrence in communities (where peace is defined in the narrow sense of the absence of violent conflict), the third is the level of disparities in the measures of personal welfare already identified above among residents in the same community. This is used to capture existing inequalities. I assume that community-wide welfare increases in infrastructure but falls in conflict episodes and in higher levels of inequality among residents. Notationally,

$$
\text { Community Welfare }=f(\text { Infrastructure, } \text { Conflict, Inequality })
$$

The link between violence and collective welfare is clear. Violent conflicts produces trauma, loss of lives and/or properties. In addition, it interrupts construction activities, thereby limiting infrastructural development, crowds out economic activities by forcing business organisations to relocate, and thus reverses the process of development (Deininger, 2003). However, the effect on personal welfare may not be as straight-forward, especially when individuals benefit materially from episodes of violence, a grim possibility in resource-abundant regions. In such setting, conflict is also most likely to accentuate inequality among individuals.

The analyses in this paper seek to examine the effects of oil (resource) availability, community location, and government presence on the measures of welfare in (1) and (2). While oil production activities may yield some benefits to local communities in terms of employment and infrastructural development, and is thus expected to improve welfare, it may have deleterious effect on human development. For example, social dislocations, unfulfilled expectations, negative environmental spillovers, may erode human welfare. Developmental initiatives or interventions by oil companies may also impact negatively on welfare and/or worsen inequality when such assistances are not tailored to meeting the particular needs of communities, or when companies use interventions as a means of "settlement" (buying peace) or a weapon of "divide-and-rule". Oyefusi $(2007,2009)$ has also argued that oil has a corrupting influence on the disposition to civil peace in the Niger Delta region, and points to the looting/secession incentive, individualized agendas, and violent rent-seeking contests arising from the interplay of oil, state predation and poor institutions.

Apart from oil, several factors can also influence each of the measures of welfare in (1). Access, educational attainments, and earnings are likely to be dependent on respondents' characteristics. In addition, 
community-level factors may influence these measures, as well as the indicators of collective welfare in (2). For example, larger infrastructural endowment and government presence in communities may lead to higher educational attainments, higher earnings, and also reduce the incidence of unemployment among residents. Government presence is likely to provide opportunity for some to derive income from the public sector, which in Nigeria traditionally pays higher wages than most private or self-employment. It may also act as a liaison centre between communities and governments thereby enhancing peace and harmony. In addition, infrastructural endowment and government presence may provide double peace dividends by reducing collective grievance and also making it easier to police communities. Community-level factors may also influence welfare disparities among individuals. For example, residents in communities that are distant from state capitals may be worse off on measures of personal welfare, but may have lower disparities. Again, more distant communities are less easy to police and may provide conducive environment for brewing civil disorder. In the same way, state-level exogenous factors may affect human development performances.

In the next section, I present methodological issues on a primary dataset from the Niger Delta region due to Oyefusi $(2008,2010)$ and which is employed in section 4 to estimate the determinants of each of the measures of welfare that has been identified above.

\section{Sample, Variables, Data and Methodological Issues}

The dataset is based on an independent survey of the Niger Delta region, which was undertaken over a six-month period from February to August 2005 (Oyefusi, 2008, 2010). The period of the survey is particularly significant for this study. Apart from the fact that the country was going through a national political reform conference which attracted much attention to the Niger Delta region, the UNDP was in the same period carrying out a background survey for its Niger Delta Human Development Report. Though the two surveys had different objectives and were independently undertaken, they both touched on welfare issues among residents in the region. However, while the UNDP survey covered the entire region, the one by Oyefusi (2008) concentrated on three states (Bayelsa, Delta and Rivers), which at the time together accounted for the bulk of Nigeria's oil production. The focus in this study is to employ the dataset by Oyefusi (2008) to analyse a different set of issues related to oil and welfare in the Niger Delta region, compare the results with some of the conclusions from the UNDP (2006), and discuss their implications for sustainable development policy in the region.

\subsection{Variables}

The core explanatory variables in this study are

Oil: This measures oil endowment in respondent's community using the number of oil wells available.

Age: This represents the age category of respondents as at the time of survey. Ages are classified into three: 1 is used to capture ages from 15 to 29 years, 2 for the ages from 30 to 45 years and 3 for ages above 45 but not more than 50 .

Asset is a dummy variable and implies that respondent has a physical asset which generates some form of income.

Distance measures the physical distance between respondent's community and the state capital using transportation cost.

Government show the extent of government presence in respondent's community as indicated by the number of federal or state government establishments.

Bayelsa: a dummy to indicate that respondent is resident in Bayelsa state

Delta: a dummy to indicate that respondent is resident in Delta state

Rivers: a dummy to indicate that respondent is resident in Rivers state

Seven variables are used to measure personal welfare. These are

Earnings: This represents respondent's income class, if employed. Income levels are classified into six. The first class (1) consists of monthly incomes of less than 7000 naira (about US\$50), the second (2) represents incomes greater than 7000 but lower than 15000 naira, the third includes all incomes that are higher than 15, 000 but less than 30,000. The fourth (4) consists of incomes greater than 30000 but lower than 60000 ; the fifth (5) incomes that are higher than 60000 but lower than 90000 , while the sixth class (6) is for incomes above 90000 (about US\$643). 
Education measures respondent's level of formal education and takes a value of 3 if respondent completed tertiary education, 2 if respondent completed secondary but not tertiary education, 1 if respondent only completed primary education and 0 if respondent did not complete primary, or has no formal, education.

Access: This reflects the socio-economic access of the respondents, including access to basic amenities, formal education and employment, and access of children or siblings to secondary or primary education. The data ranges from 0 to 11 .

Unemployment, a dummy variable which indicates that respondent was unemployed and was also not a full-time student in any educational institution or an apprentice in vocational training at the time of survey.

Education_Unemployment shows the formal educational attainment of the unemployed.

Unemployment_duration. This measures how long respondent has been in a state of unemployment. It takes on a value of 0 if respondent is not unemployed or idle at the time of survey, 1 if he has been unemployed (idle) for not more than three months, 2 if respondent has been unemployed (idle) for more than three months but less than one year, 3 if respondent has been unemployed (idle) for more than one but less than three years, and 4 if respondent has been in a state of unemployment (idleness) for three years or more.

Hope is a dummy indicating that respondent expressed hope or expectation about the future. It is thus an indicator of optimism on the part of respondent.

Five variables are used to illustrate collective welfare as follows

Infrastructure shows the level of physical infrastructure in respondent's community including paved roads, public schools, public hospitals, and other public projects, such as town halls or recreational sites.

Conflict is a count variable derived from the number of violent conflict episodes in respondent's community between January 1995 and March 2005.

Education Dispersion: This is the standard deviation of education for each community and indicates the extent of inequality in educational attainments among residents. Its value ranges from 0.4925 to 0.8273 .

Earnings Dispersion, the standard deviation of Earnings for each community, has values ranging from 0.4832 to 1.7696.

Access Dispersion, which is the standard deviation of Access for each community illustrates the level of inequality in socio-economic access among residents. Its value ranges from 0.6418 to 2.2457 (NOTE 2).

\subsection{Estimation Techniques}

Different regression techniques are used to estimate the determinants of the measures of welfare in (1) and (2), depending on the nature of the underlying data. Ordered Logit regression is used for those based on ordered data, such as Earnings, Education, Education_Unemployment, Unemployment_duartion. For dichotomous variables (such as Unemployment and hope), the Ordinary Logit regressionis employed while Poisson regressionis usedfor variables with count data (such as Infrastructure, Conflict). For other variables (such as Access, Access Dispersion, Education Dispersion, and Earnings Dispersion), the ordinary regression method is used (see Long (1997) for a discussion of these techniques, and the justification for their use).

\section{Results From Data Analyses}

\subsection{What Tops the Need-List of People in Resource-Rich Communities?}

The first level of analyses provides a descriptive assessment of the personal needs of respondents (Figure 1). The result indicates that economic security (employment that guarantees a living wage) tops the list, followed by infrastructure. Similar assessment by the UNDP (2006) shows that socio-economic infrastructure tops the concerns of people in the Niger Delta region with educational facilities considered the most important, followed by good water supply, and health facilities. The survey by the Niger Delta Development Commission (NDDC) (see UNDP 2006:396) also places education as a more crucial need than infrastructure. These differences in outcomes between the two surveys and this study may be due to differences in the scope of the surveys and the type of questions asked, the way the questions are structured, or in focus or emphasis. In particular, the assessment in this study is based on the question 'What is your most pressing need', with respondents having the opportunity to provide a ranking of choices or write out a choice that is not included among the options (see to Oyefusi, 2007, 2008). However, what the results from the three studies suggest is that absolute control over local resources by people in resource-abundant regions may not be as important to them as achieving an enhanced human development. Only about 25 percent of respondents in the survey by Oyefusi (2007) indicated resource control as a most pressing need. 


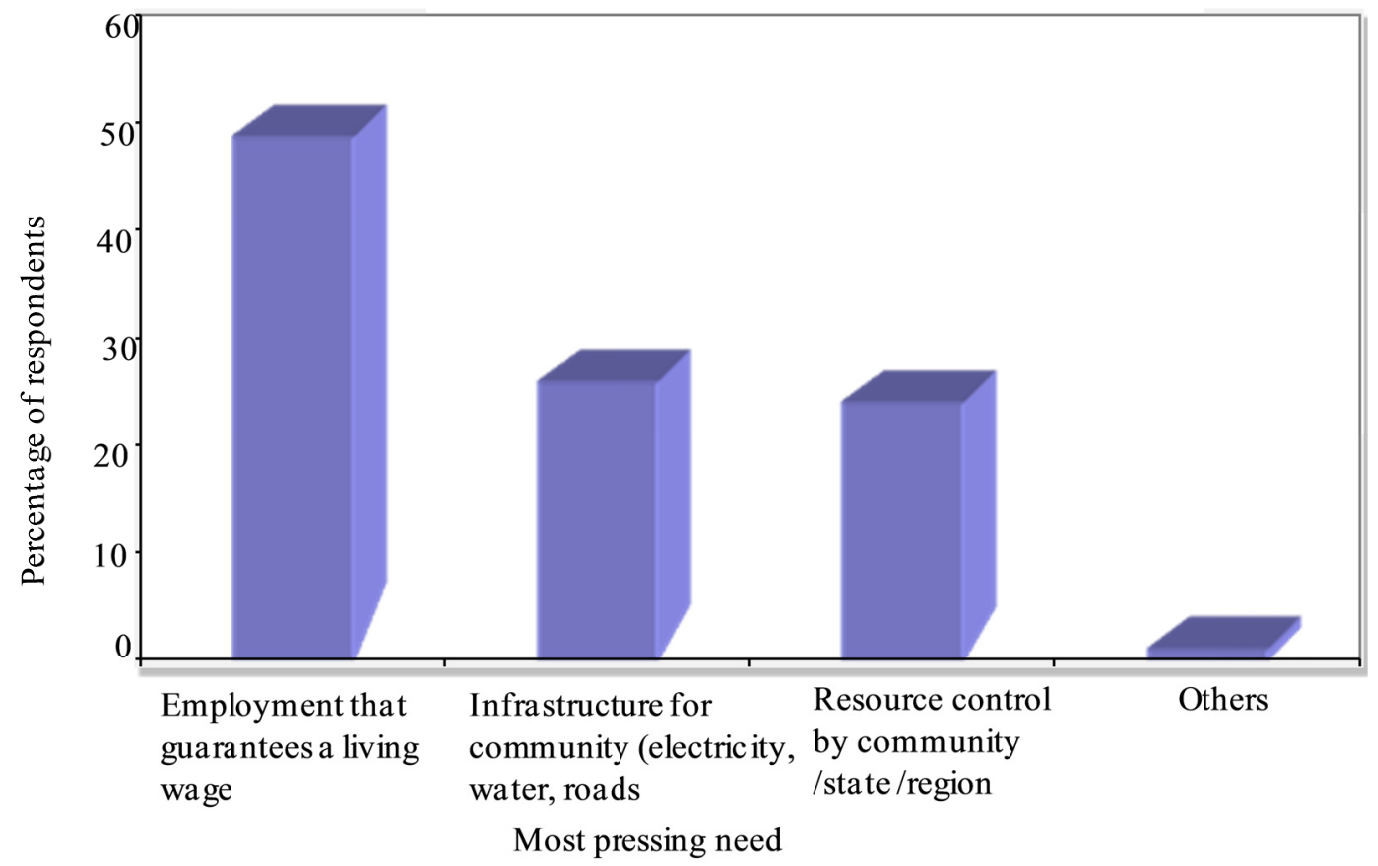

Figure 1. Needs assessment of residents in the Niger Delta region

Source: Based on Oyefusi (2007, 2008).

\subsection{Oil and Personal Welfare}

The regression results (Table 1a, Model 1) suggest that oil does not have any significant influence on earning levels among residents in a community; those in communities with larger oil endowments are not necessarily likely to enjoy higher income than those in communities with little or no oil. While oil-availability is negatively correlated with earnings showing that income is generally lower in oil communities and thus providing some support for observation by the UNDP $(2006: 160,163)$ that local government areas with oil facilities are worse off on HPI scores in comparison to those without such facilities, the correlation is not explained by the latter. Rather, in line with theoretical expectations, earnings are significantly influenced (raised) by educational attainments, age, asset-possession, government presence and distance of communities.

However, oil does have significant positive influence on educational attainments and socio-economic access (Model 2, Table 1a). All else the same, residents in communities with oil tend to have, on average, higher levels of formal education. These finding contradicts that of the UNDP (2006:153), which notes lower educational performance for most localities with high human development index (HDI) scores, a situation that is reported to be more pronounced in communities with oil facilities. However, there are many other factors that explain educational attainments, such as age and distance of communities from capital. Ironically, communities with larger socio-economic infrastructure tend to have larger number of persons with lower educational attainments. This appears to cast doubt on the efficiency of public infrastructures, particularly public schools, in these communities. Oil also raises access of residents (Table 1a, Model 3); persons in communities with little or no oil endowment tend to have little personal socio-economic access. As expected, access also increases with age of respondents and the level of infrastructural endowment in community. 
Table 1a. Determinants of personal welfare indicators among residents in the Niger Delta: earnings, education and access

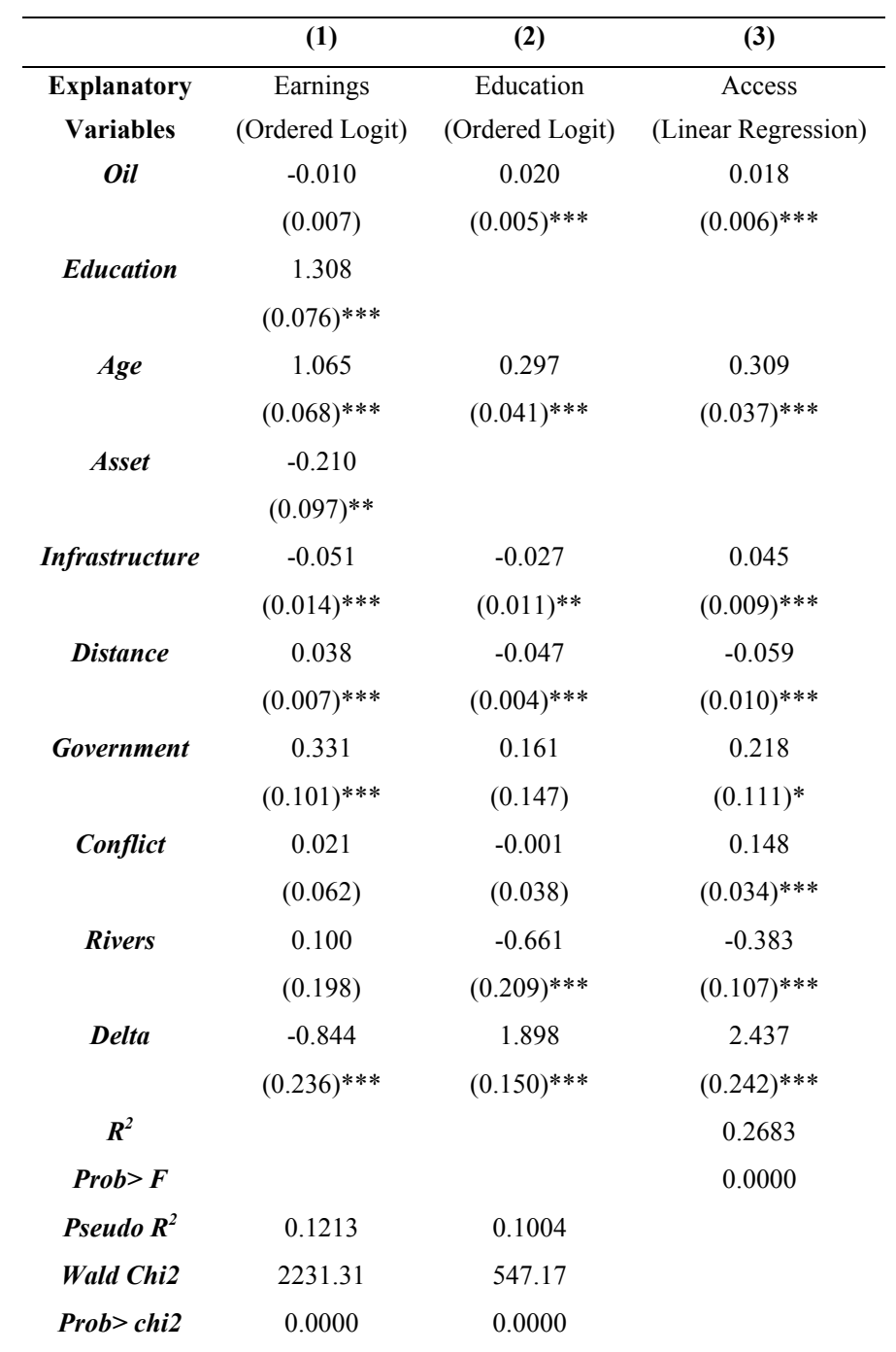

Notes: Robust standard errors in parentheses. * means significant at $10 \%$; ** means significant at $5 \%$; *** means significant at $1 \%$ All regressions are with constant terms.

Though oil is negatively correlated with unemployment, it does not explain the incidence (Table $1 \mathrm{~b}$, Model 4). It appears that the oil industry in the Niger Delta has not been able to provide meaningful linkages with the broader economy in a way that is capable of expanding activities and employment opportunities in communities. As the UNDP (2006:376) observes, most of those employed in the region (between 75 to 85 percent) are found in the informal sector. In addition, the likelihood that a person will be unemployed falls with age and educational attainment. Interestingly, the behaviour of the other indices of unemployment (such as the interactive variable between unemployment and formal educational attainment, Educated_unemployed, and the spell of unemployment, Unployment_duration) follows the same pattern (Table 1b, Models 5 and 6). 
Table 1b. Determinants of Personal Welfare Indicators among Residents in the Niger Delta: Unemployment and Hope

\begin{tabular}{|c|c|c|c|c|}
\hline & (4) & (5) & (6) & (7) \\
\hline $\begin{array}{l}\text { Explanatory } \\
\text { Variables }\end{array}$ & $\begin{array}{l}\text { Unemployment } \\
\text { (Logit) }\end{array}$ & $\begin{array}{c}\text { Educated_Unployment } \\
\text { (Ordered Logit) }\end{array}$ & $\begin{array}{l}\text { Unemployment_duration } \\
\text { (Ordered Logit) }\end{array}$ & $\begin{array}{l}\text { Hope } \\
\text { (Logit) }\end{array}$ \\
\hline Oil & $\begin{array}{l}-0.008 \\
(0.009)\end{array}$ & $\begin{array}{l}-0.004 \\
(0.009)\end{array}$ & $\begin{array}{l}-0.008 \\
(0.009)\end{array}$ & $\begin{array}{c}-0.130 \\
(0.022)^{* * *}\end{array}$ \\
\hline Education & $\begin{array}{c}-0.516 \\
(0.091)^{* * *}\end{array}$ & & $\begin{array}{c}-0.526 \\
(0.090)^{* * *}\end{array}$ & $\begin{array}{c}-1.974 \\
(0.303)^{* * *}\end{array}$ \\
\hline Age & $\begin{array}{c}-0.457 \\
(0.064)^{* * *}\end{array}$ & $\begin{array}{c}-0.322 \\
(0.062)^{* * *}\end{array}$ & $\begin{array}{c}-0.451 \\
(0.063)^{* * *}\end{array}$ & $\begin{array}{l}-0.677 \\
(0.310)^{*}\end{array}$ \\
\hline Asset & & & & $\begin{array}{l}-0.532 \\
(0.618)\end{array}$ \\
\hline Infrastructure & $\begin{array}{l}-0.022 \\
(0.020)\end{array}$ & $\begin{array}{l}-0.011 \\
(0.020)\end{array}$ & $\begin{array}{l}-0.025 \\
(0.021)\end{array}$ & $\begin{array}{c}-0.070 \\
(0.032)^{* * *}\end{array}$ \\
\hline Distance & $\begin{array}{c}-0.052 \\
(0.009)^{* * *}\end{array}$ & $\begin{array}{c}-0.042 \\
(0.009)^{* * *}\end{array}$ & $\begin{array}{c}-0.049 \\
(0.008)^{* * *}\end{array}$ & $\begin{array}{c}0.043 \\
(0.007)^{* * *}\end{array}$ \\
\hline Government & $\begin{array}{c}-0.444 \\
(0.066)^{* * *}\end{array}$ & $\begin{array}{c}-0.368 \\
(0.072)^{* * *}\end{array}$ & $\begin{array}{c}-0.439 \\
(0.069)^{* * *}\end{array}$ & $\begin{array}{l}-0.186 \\
(0.430)\end{array}$ \\
\hline Conflict & $\begin{array}{c}-0.206 \\
(0.076)^{* * *}\end{array}$ & $\begin{array}{c}-0.200 \\
(0.078)^{* *}\end{array}$ & $\begin{array}{c}-0.209 \\
(0.076)^{* * *}\end{array}$ & $\begin{array}{c}-0.835 \\
(0.081)^{* * *}\end{array}$ \\
\hline Rivers & $\begin{array}{c}-0.770 \\
(0.182)^{* * *}\end{array}$ & $\begin{array}{c}-0.900 \\
(0.192)^{* * *}\end{array}$ & $\begin{array}{c}-0.809 \\
(0.186)^{* * *}\end{array}$ & $\begin{array}{c}4.610 \\
(0.404)^{* * *}\end{array}$ \\
\hline Delta & $\begin{array}{l}-0.198 \\
(0.236)\end{array}$ & $\begin{array}{l}-0.251 \\
(0.246)\end{array}$ & $\begin{array}{l}-0.346 \\
(0.245)\end{array}$ & $\begin{array}{c}-2.023 \\
(0.443)^{* * *}\end{array}$ \\
\hline Earnings & & & & $\begin{array}{c}0.149 \\
(0.102)^{* * *}\end{array}$ \\
\hline Access & & & & $\begin{array}{c}3.772 \\
(0.481)^{* * *}\end{array}$ \\
\hline Pseudo $R^{2}$ & 0.1128 & 0.0613 & 0.0991 & 0.8978 \\
\hline Wald Ch & 320.61 & 161.18 & 315.90 & 10061.82 \\
\hline Prob $>$ chi2 2 & 0.0000 & 0.0000 & 0.0000 & 0.0000 \\
\hline
\end{tabular}

Notes: Robust standard errors in parentheses. ${ }^{*}$ means significant at $10 \%$; $*$ means significant at $5 \%$; *** means significant at $1 \%$ All regressions are with constant terms.

\subsection{Oil and Collective Welfare}

In line with theoretical expectations, oil-availability raises the likelihood of higher infrastructural endowment in communities; communities with little or no oil tend to be poor in infrastructure (Model 1, Table 2). But it also significantly raises the incidence of violent conflict episodes in communities (Model 2, Table 2) (NOTE 3). In other words, communities with oil endowments tend to experience larger incidences of violent conflict. Oil-availability also significantly reduces the likelihood of wider variations in educational attainments among individuals in the same community, and is negatively (positively) correlated with higher variations in earnings (socio-economic access), though the relationships are not statistically significant (Table 3). These results are measurably consistent with observations by the UNDP (2006: 160) that disparities in HPI rankings were lowest for states with larger oil endowments. Other factors explaining variations in the personal measures of welfare (education, earnings, and access) among respondents from a given community are the location of community (distance) and historical conflict episodes. Government presence and infrastructural endowments in community also have weak statistical influences. In line with theoretical expectations, larger infrastructural endowment weakly reduces the likelihood of higher variations in socio-economic access. 
Table 2. Determinants of Community-Wide Indicators of Welfare in the Niger Delta: Infrastructure and Conflict Episodes

\begin{tabular}{ccc}
\hline \multirow{2}{*}{$\begin{array}{c}\text { Explanatory } \\
\text { Variables }\end{array}$} & $\mathbf{( 1 )}$ & $\mathbf{( 2 )}$ \\
\cline { 2 - 3 } Oil & $\begin{array}{c}\text { Infrastructure } \\
\text { (Poisson) }\end{array}$ & $\begin{array}{c}\text { Conflict } \\
\text { (Poisson) }\end{array}$ \\
\hline Infrastructure & 0.025 & 0.0453 \\
& $(0.005)^{* * *}$ & $(0.044)^{* * *}$ \\
Distance & & -0.015 \\
& & $(0.010)$ \\
Government & -0.001 & 0.014 \\
& $(0.003)$ & $(0.003)^{* * *}$ \\
Conflict & -0.003 & 0.116 \\
& $(0.035)$ & $(0.060)^{*}$ \\
Rivers & -0.067 & \\
& $(0.027)^{* *}$ & -0.288 \\
Delta & -0.048 & $(0.104)^{* * *}$ \\
& $(0.053)$ & -1.044 \\
Wald Chi2 & -0.538 & $(0.118)^{* * *}$ \\
Prob>chi2 & $(0.074)^{* * *}$ & 248.59 \\
& 108.95 & 0.0000
\end{tabular}

Notes: Robust standard errors in parentheses. * means significant at $10 \%$; ** means significant at $5 \%$; *** means significant at $1 \%$ All regressions are with constant terms.

\subsection{Does Resource Abundance Create Hopelessness?}

The data employed in this study corroborates UNDP's (2006:385) finding that majority of people in the Niger Delta region have high hopes in the future. However, the regression analyses show that oil-availability significantly erases hope among residents (Table 1b, Model 7). Age exhibits the same ravaging effect; the older people become, the more hopeless they tend to be. But individuals with larger socio-economic access tend to be more hopeful. Surprisingly, hope is absent for individuals with higher formal educational attainments and also for those resident in communities with larger infrastructure. While the tendency for oil to promote hopelessness may not be too surprising in the context of the Niger Delta region, the effect of higher education is counterintuitive. Oyefusi $(2008,2010)$ has argued that higher education tends to increase personal grievances among residents in the region by bringing greater awareness of one's environment, rights, and what ought to be one's entitlements. This study suggests that it also has a corrosive effect on hope. Further research in this area may prove useful; in particular, the extent to which higher educational attainments among individuals in communities with exhaustible natural resources makes them heavily discount the future. 
Table 3. Determinants of Disparities in Some Indicators of Personal Welfare among Residents in Same Community in the Niger Delta

\begin{tabular}{cccc}
\hline & $\mathbf{( 1 )}$ & $\mathbf{( 2 )}$ & $\mathbf{( 3 )}$ \\
\hline Explanatory & Education & Earnings Dispersion & Access Dispersion \\
Varaibles & Dispersion & & \\
Oil & -0.001 & -0.001 & 0.002 \\
& $(0.001)^{*}$ & $(0.002)$ & $(0.002)$ \\
Infrastructure & -0.001 & 0.000 & -0.004 \\
Government & $(0.001)$ & $(0.002)$ & $(0.002)^{*}$ \\
& 0.006 & 0.067 & 0.024 \\
Conflict & $(0.007)$ & $(0.020)^{* * *}$ & $(0.017)$ \\
& 0.007 & 0.059 & 0.011 \\
Distance & $(0.003)^{* *}$ & $(0.009)^{* * *}$ & $(0.009)$ \\
& -0.005 & -0.011 & -0.020 \\
Delta & $(0.000)^{* * *}$ & $(0.001)^{* * *}$ & $(0.001)^{* * *}$ \\
& 0.131 & 0.539 & 0.571 \\
Rivers & $(0.012)^{* * *}$ & $0.051)^{* * *}$ & $(0.058)^{* * *}$ \\
& -0.012 & 0.201 & 0.011 \\
Observations & $(0.014)$ & $(0.040)^{* * *}$ & $(0.037)$ \\
R-squared & 1348 & 1348 & 1348 \\
\hline
\end{tabular}

Notes: Robust standard errors in parentheses. ${ }^{*}$ means significant at $10 \%$; $*$ means significant at $5 \%$; *** means significant at $1 \%$. All regressions are with constant terms.

\subsection{Resource-Related Conflict and Welfare}

It is worthwhile highlighting the effect of violent conflicts on each of the indicators of welfare employed in this study. While conflict has no statistically significant effect on earnings and education among individuals; it significantly raises access, and reduces the likelihood of unemployment, the likelihood of staying longer in unemployment and the incidence of unemployment among the highly educated. It also has statistically significant negative effect on hope (Table 1b, Model 7) and infrastructure (Table 2, Model 1). Communities with frequent outbreaks of violence tend to be poor in infrastructural endowments and the residents tend to be hopeless. In addition, higher episodes of conflict lead to wider variations in all but one of the measures of welfare. Conflict significantly raises divergence in educational attainments and earnings among residents and is also positively correlated with (but not statistically related to) larger variations in socioeconomic access (Table $3)$.

It is worthy of note that while episodes of conflict negatively affect some personal welfare measures, it improves on others and leave some others unchanged. In particular, the beneficial effect of higher incidence of violent conflict on employment and socio-economic access of residents appears to contradict theoretical expectation that conflict crowds out economic activities. But there appear to be plausible explanations. First, the results tend to show a pattern: violent conflict episodes erodes psychological measures of personal welfare (such as hope), have no significant effect on measures that are based on formal engagements (such as educational attainments and earnings from formal employment), but raises other measures that are less formal (such as personal socio-economic access, and informal employment) through the opportunities they provide for personal gain. Material benefits derive from "conflict settlements" easily improves personal socio-economic access and assist some to break the spell of unemployment (by providing start-up capital for self-employment, for example), but does not necessarily influence decisions to acquire formal education (a choice often determined by several other factors) or provide formal employment (Note 4). These benefits also tend to accrue to a few thereby raising inequality. We now turn to the roles of government presence and location of communities. 


\subsection{What Does Government Presence Do in Resource-Rich Regions?}

Government presence in communities has positive impact on earnings and socio-economic access among residents and reduces the likelihood of being unemployed or experiencing a longer spell of unemployment. But it also reduces hope (Table 1, Model 7), leads to higher episodes of violent conflict (Table 2, Model 2) and raises inequality in earnings among residents (Table 3). It appears that the benefit of higher earnings associated with the presence of government establishments tends to be highly unequally distributed. Residents who are able to gain employment in such organizations/institutions/agencies or access opportunities for business engagements benefit acutely above others. This may also partly explain why government presence raises conflict. Such agencies may have served as avenues for rent-seeking and patronage thereby inducing violent conflicts among residents. In addition, they may have failed to act effectively as a liaison between communities and governments and carry out their activities in a way that enhance peace and security.

\subsection{Are More Distant Communities Better Off?}

As earlier explained, communities located far away from political and administrative centres of resource-rich state are expected to be highly disadvantaged. First, government presence may be totally lacking and it is easy for them to be excluded from enjoying some public goods and infrastructure. They may also be safe havens for armed gangs, so that they experience more frequent incidences of conflict. The regression results show that educational attainments and socio-economic access tend to be lower in more-distant communities. However, residents in such communities tend to be better-off than those in communities closer to state capitals on five other indicators of personal welfare (earnings, unemployment, educated_unemployed, unployment_duration, and hope). In other words, the likelihood of higher incidence of unemployment among residents, of a higher concentration of "educated unemployed", the tendency for the duration of unemployment to be longer, the likelihood that individuals will be engaged in informal activities yielding marginal earnings so that income level is lower on average, and the tendency for residents to be disillusioned are lower in communities further away from state capitals.

These results are not altogether surprising. Communities close to state capitals in regions that host mineral resources, such as oil, tend to attract a large flow of job-seekers, including those with high levels of formal educational attainments. But because the oil industry is highly capital-intensive and predominantly an enclave, most end up disappointed and eking out a living at the margin. In contrast, residents in more distant communities may have freed themselves from the illusion of formal employment and resigned to rural living, finding employment in land-based activities and thereby escaping the trauma that goes with shattered expectations. The same arguments may explain the relationship between infrastructure and hope. As can be seen from Table 2, more distant communities generally have less endowment of socio-economic infrastructure in comparison to those close to state capitals. Higher infrastructural endowments in the latter are often one of the factors that encourage the immigration of large number of job-seekers, but this does not necessarily guarantee employment or higher earnings. Table 1a (Model 1) shows that on average, earnings tends to fall with infrastructural endowment.

\subsection{Are Youths in Resource-Rich Regions More Vulnerable?}

The UNDP report on the Niger Delta (UNDP 2006:174) notes that "underprivileged" groups, such as youths and women suffer the most from the "socio-economic deprivation" in the region (Note 5). The survey on which this study is based focused on males, so it is impossible to test the effect of oil on the welfare of women. However, it assists us to show the effect of age on the measures of personal welfare employed, thereby producing some insights into the effect of resource-abundance on male youths. Table 1a shows that earnings increases with age of respondents. The same applies to education and access. All else being equal, the younger is the respondent, the more likely he will score low on these measures. In the same way, unemployment, educated_unemployed, as well as unployment_duration falls with age, suggesting that younger individuals are more likely to be unemployed and to stay longer in that condition than older ones with the same formal educational attainments. These broad results tend to corroborate observation by the UNDP (2006). However, the results in Table $1 \mathrm{~b}$ also show that hope falls with age of respondents. Holding other variables constant, the younger is the individual, the more likely is he to be optimistic about the future.

\subsection{Resource Abundance and Peculiarities}

It is interesting to note the effect of state-level differences on personal and collective welfare of residents in resource-rich regions. The results show that these factors are significant for the Niger Delta. For example, residents in Rivers State exhibit significant differences in all welfare indicators (except earnings) from those in Bayelsa. But the differences do not tell a one-way story. While educational attainments and socio-economic 
access tend to be lower for residents in Rivers state, the likelihood of being unemployed, staying longer in a state of unemployment and of the more-highly-educated being without job is also lower (Table 1b). In addition, communities in the state tend to have lower episodes of violent conflicts (Table 2) while residents tend to exhibit greater hope. But income inequality tends to be higher among residents (Table 3). The same mixed scenario is observed for residents in Delta state compared to Bayelsa. Educational attainment and socio-economic access tend to be higher for residents in the former but earnings tend to be lower on average and residents tend to be less hopeful (Table 1a and b). Infrastructural endowments and conflict episodes also tend to be lower in the state (Table 2). In addition, the effect of state-level characteristics on divergences in personal welfare measures is most pronounced for Delta state where such factors raise the likelihood of higher disparities in educational attainments, earnings, and socio-economic access.

Are these results consistent enough for meaningful deductions? They appear to be. First, the likelihood of an individual having higher scores on the measures of personal welfare appears to be highest if he is resident in Delta state. Interestingly, this agrees with observation in the UNDP (2006:141) report which shows that the state actually performed best in human poverty index ranking in the Niger Delta. However, the tendency for inequality to be higher among residents is also greatest in the State, followed by Rivers, while the likelihood of higher conflict episodes is most pronounced in Bayelsa. These results may not be unconnected with the peculiar geographical condition of Bayelsa state (that is, its most difficult terrain) which limits opportunities and make it easy for armed gangs to find shelter. In 2005 , the Governor of the state openly lamented the unusually high tendency to violent conflict among residents.

\section{Concluding Notes: What Can We Learn and Recommend for Policy and Further Research?}

In this paper, I have examined the determinants of welfare among individuals and communities in the Niger Delta region of Nigeria. The focus has been to find out whether natural resources (in this case oil) enhances or erodes welfare at both personal and community levels, and to look at the effect of such factors as location and government presence. The results revealed a mixed effect. Oil enhances some measures of welfare but does not significantly influence others. It also tends to generate violent conflicts in communities, which raises personal inequality, and to promote a feeling of despondency among individuals. Government presence in communities raises earnings on the average but it also raises inequalities in income and the likelihood of higher episodes of violent conflict (thus reducing collective welfare). More distant communities tend to be better off than those closer to administrative and political capitals on some measures of welfare but are worse off on other measures. The risk of violence is higher when such communities have oil endowments. State-level factors/differences are also found to significantly affect welfare levels and divergences suggesting that geographical characteristics (exogenous factors) may prove to be a serious factor in the determination of welfare in resource-rich regions just the same way as policy and initiatives at the local level.

It appears that natural resources can be significantly welfare-improving if its tendency to encourage violent conflict outbreaks can be addressed. This will not be achieved by merely providing greater infrastructure or expanding educational opportunities, even though these are necessary. As this study shows, education is not likely to create or promote hope in itself; it may even fracture hope and raise the disposition to non-violent forms of protests (see Oyefusi, 2010) if expansions are not matched with increased economic opportunities. To effectively reduce violence, there would be the need to eliminate or reduce the rent-seeking contests occasioned by a loose or privileged access to resource wealth, and to establish, develop, or strengthen conflict prevention and resolution mechanism at the local level. This should guide the form of arrangements made to make local communities benefit from resource wealth. There is also the need to make government presence in communities more effective rather than being avenues for rent-seeking and to adopt economic/developmental policies that are capable of reversing the drift of job-seekers to the administrative centers of resource-rich states. This inevitably calls for initiatives that lead to economic diversification.

The influence of location on welfare in resource-rich regions is an issue that may require further research, so also is the suggested relationship between higher educational attainments and hope among residents. Are more-distant-communities actually better-off on some measures of welfare? Does higher education or greater knowledge bring greater feeling of destitution or hopelessness or lead to greater incidences of conflict in resource-abundant communities, especially when expectations have been severally and severely dashed? Since this paper is based on a case study, it is not possible to make conclusive deductions. In addition, there is the need to test the consistency of some of the results of the study using more recent household data on the Niger Delta. Finally, it is pleasantly surprising that one of the apparently most disadvantaged groups in the region (the youths) also tends to exhibit greater optimism, a force which many (see UNDP, 2006: 385) agree could be harnessed to bring about positive transformation. 


\section{References}

Deininger, K. (2003). Causes and Consequences of Civil Strife: Micro-level Evidence from Uganda. Oxford Economic Papers, 55(4), 579-606. http://dx.doi.org/10.1093/oep/55.4.579

Gary, I., \& Karl T. L. (2003). Bottom of the Barrel, Africa's Oil Boom and the Poor. Retrieved from http://www.crsprogramquality.org/storage/peacebuilding/Bottom\%20of\%20the\%20barrel.pdf

Gravin, M., \& Hausmann, R. (1998). Nature, Development, and Distribution in Latin America: Evidence on the Role of Geography, Climate and Natural Resources. Inter-American Development Bank IADB Office of the Chief Economist Working Paper No. 378. http://dx.doi.org/10.1017/S0043887100008200

Long, J. S. (1997). Regression Models for Categorical and Limited Dependent Variables: Advanced Quantitative Techniques in the Social Sciences Series. London: SAGE Publications.

Oyefusi, A. (2007). Oil-dependence and Civil Conflict in Nigeria. Centre for the Study of African Economies (CSAE), University of Oxford, WP 2007-09. Retrieved from http://economics.ouls.ox.ac.uk/13225/1/200709text.pdf

Oyefusi, A. (2008). Oil and the Probability of Rebel participation among Youths in the Niger Delta of Nigeria. Journal of Peace Research, 45(4), 539-555. http://dx.doi.org/10.1177/0022343308091360

Oyefusi, A. (2009). Trust and the Breakdown of Civil Order in Nigeria's Delta Region: Evidence from Historical Conflict Episodes. The Round Table (Commonwealth Journal of International Affairs), 98(403), 483-492. http://dx.doi/abs/10.1080/00358530903018095

Oyefusi, A. (2010). Oil Youths, and Civil Unrest in Nigeria's Delta: The Role of Schooling, Educational Attainments, Earnings, and Unemployment. Conflict and Peace Management Science, 27(4), 326-346, http://dx.doi.org/10.1177/0738894210374399

Ross, M. L. (1999). The Political Economy of the Resource Curse. World Politics, 51(2), 297-322. http://dx.doi.org/10.1017/S0043887100008200

Ross, M. L. (2001). Does Oil Hinder Democracy? World Politics, 53(April), 325-61. http://dx.doi.org/10.1353/wp.2001.0011

Ross, M. L. (2004). Mineral Wealth and Equitable Development.Background Report for the World Development Report 2006. Retrieved from http://www.sscnet.ucla.edu/polisci/faculty/ross/MineralEquitableDev.pdf

Sachs, J. D., \& Warner A. M. (1995). Natural Resources Abundance and Economic Growth. Development Discussion Paper No. 517a. Harvard Institute for International Development. Cambridge, MA. Retrieved from http://www.cid.havard.edu/hiid/517.pdf

United Nations Development Programme (UNDP). (2006). Niger Delta Human Development Report. Abuja: UNDP. Retrieved from http://hdr.undp.org/en/reports/nationalreports/africa/nigeria/nigeria_hdr_report.pdf

\section{Notes}

Note1. An amnesty deal between government and militants brokered late last year has secured some measure of 'peace' in the region. However, the possibility of a return to violence remains.

Note 2. A more detailed description of most of these variables, the associated data and how the method of data generation can be found in Oyefusi $(2008,2010)$.

Note 3.The regression does not include variables that capture individual-level characteristics since they relate to the present period while the data on conflict is historical.

Note 4. On the other hand, violent conflict may lead to interruptions in formal education, while the material benefits it offers some may actually reduce the need for formal education. However, the results do not provide enough evidence to support these propositions. While they show a negative relationship between formal educational attainment among residents and conflict episodes in communities, the relationship is not statistically significant. In other words, other factors other than conflict outbreaks explain this outcome

Note 5. This assertion is debatable though, considering the rent-seeking activities of various youth groups in the region. However, only a few tend to benefit from these activities. 


\section{Copyrights}

Copyright for this article is retained by the author(s), with first publication rights granted to the journal.

This is an open-access article distributed under the terms and conditions of the Creative Commons Attribution license (http://creativecommons.org/licenses/by/3.0/). 